\title{
Conserving a globally threatened species in a semi-natural, agrarian landscape
}

\author{
Harriet Ibbett, Chansetha Lay, Ponlork Phlai, Det Song, Chaman Hong \\ Simon P. MAHood and E. J. Milner-Gulland
}

\begin{abstract}
Agriculture threatens biodiversity across the tropics, particularly in semi-natural grassland landscapes, where human populations are high, habitat is easily converted and agriculture is prone to intensification. Over the last 20 years intensive, commercial dry season rice cultivation has emerged as the dominant threat to the Bengal florican Houbaropsis bengalensis, a globally threatened bustard that breeds in the seasonally inundated grasslands of central Cambodia. Although floricans have been extensively monitored for 10 years, no socioeconomic research has been undertaken to examine how local livelihood activities interact with the florican. We conducted household questionnaires and focus groups in 21 villages in the Northern Tonle Sap Conservation Landscape to gather information on household demographics, rice farming and bird hunting in protected and unprotected areas of florican breeding habitat. We identified a significant increase in dry season rice adoption by local communities since 2005 . Dry season rice cultivation was strongly associated with agrochemical use and rice fields directly overlapped with florican breeding habitat, reducing habitat availability throughout the breeding season. We identified a low but significant level of bird hunting in grassland households (8\%) and revealed a demand for wild bird meat amongst local communities. Our findings suggest an urgent need for conservation interventions in unprotected farmland and emphasize the role of enforcement and community engagement in improving protection within protected areas. We highlight the potential of private sector initiatives such as the Sustainable Rice Platform in reconciling conservation and development for impoverished rural communities.
\end{abstract}

Keywords Agricultural intensification, Bengal florican, Cambodia, dry season rice, hunting, livelihoods, protected areas

\footnotetext{
HARRIET IBBETT $^{*}$ (Corresponding author) Department of Life Sciences, Imperial College London, Silwood Park Campus, Ascot, UK

E-mail Harriet.ibbett@zoo.ox.ac.uk

Chansetha Lay, Ponlork Phlai, Chamnan Hong and Simon P. Mahood † Wildlife Conservation Society, Phnom Penh, Cambodia

DET Song Faculty of Agricultural Economics \& Rural Development of the Royal University of Agriculture, Ecoland Research Centre, Phnom Penh, Cambodia

E. J. Milner-GulLand Department of Zoology, University of Oxford, Oxford, UK

${ }^{*}$ Present address: Department of Zoology, University of Oxford, The Tinbergen Building, South Parks Road, Oxford, OX1 3PS, UK

$\dagger$ Also at: Research Institute for the Environment and Livelihoods, Charles Darwin University, Darwin, Northern Territory, Australia

Received 5 September 2016. Revision requested 20 October 2016.

Accepted 1 December 2016. First published online 29 May 2017.
}

\section{Introduction}

Cor millennia humans have affected the landscapes in which they live. In Europe, preserving semi-natural habitats dominates conservation priorities, yet in the tropics anthropogenic landscapes receive little public attention or conservation effort (Wright et al., 2012). This is especially true of grassy biomes such as grassland, savannah and steppe, where landscape structure is often maintained through complex human-wildlife and ecological interactions (Curtin \& Western, 2008). To date, grassy biomes have largely been overlooked in conservation, viewed as degraded lands or considered in terms of their potential for forest restoration (Bond \& Parr, 2010). Yet globally, nearly half of Centres of Plant Diversity include grassland habitat, and grasslands support over 10\% of Endemic Bird Areas (White et al., 2000). Over the next 50 years demand to convert natural habitat and intensify agriculture will escalate, especially in developing countries (Tilman et al., 2001; Green et al., 2005). Tropical grasslands, where land can be converted with ease and pressure to intensify is greatest, are inherently threatened (White et al., 2000). Losses of grasslands to agriculture may exceed those of tropical rainforests (Hoekstra et al., 2005; Parr et al., 2014), threatening the survival of tropical grassland species and the habitats on which they depend (Wright et al., 2012).

Lowland tropical grasslands are typically found in river floodplains. In South-east Asia the Tonle Sap floodplain in Cambodia contains the largest remaining example of seasonally inundated grassland in the region (BirdLife International, 2003). This grassland is of high importance for the Bengal florican Houbaropsis bengalensis, a Critically Endangered bustard with an estimated global population of 350-1,500 individuals (BirdLife International, 2015). The species' global distribution is restricted to two disjunct populations: India and Nepal's terai grasslands, and the Tonle Sap floodplain, which supports $60 \%$ of the global population (BirdLife International, 2015). In Cambodia the suitability of grassland habitat for the florican is maintained by low intensity land-use practices such as burning, livestock grazing, and cultivation and fallowing of traditional wet season rice (Gray, 2008). These practices mimic functions once provided by now extinct megafauna (Packman et al., 2014).

Since 1995 the Tonle Sap grasslands have been subject to rapid land-use change. In 1995-1996 grassland was estimated to cover $30 \%$ of the floodplain but by $200546 \%$ of this natural grassland cover had been lost, primarily as a 
result of aggressive scrub expansion and agricultural abandonment by inner-floodplain communities (Packman et al., 2013). Since 2004 the loss of grassland has been compounded by the emergence of dry season rice, a form of intensive, irrigated rice cultivation that relies on the construction of large-scale dam and canal networks (Packman et al., 2014). Dry season rice expansion was initially driven by Economic Land Concessions (long-term land development leases) granted by the government to influential urban elites (Packman et al., 2013). However, recent research suggests local communities have capitalized on irrigation investments made by concessionaires and are also converting grasslands for dry season rice (Mahood \& Hong, 2013), a trend that remains unquantified. Dry season rice is now thought to be the greatest threat to florican survival, with $44-66 \%$ population declines recorded for the Tonle Sap population since the emergence of dry season rice cultivation in 2004 (Packman et al., 2014), although studies suggest hunting may also threaten the species (Packman, 2011).

To develop effective conservation interventions, policymakers and conservation managers require detailed understanding of drivers of biodiversity loss, including knowledge of the direct effects of human activities on ecosystems, and understanding of how conservation interventions are modulated through human behaviour (Milner-Gulland, 2012). In the case of the florican, ecological studies have documented population declines and habitat loss (Gray, 2008; Packman, 2011), yet in-depth understanding of how local people use the grassland landscape and directly and indirectly interact with florican populations remains limited. Although the livelihood activities of people living in the landscape were documented in 2005 (Gray, 2008), the rapidly evolving socioeconomic context means that these findings are now substantially outdated. Florican use of grasslands for display, breeding and foraging is highly seasonal, and it is essential to understand how changes in the characteristics, timing and extent of livelihood activities over the past 10 years might have changed human-florican interactions. Without sufficient understanding of the various cultural, political, economic and demographic factors that drive land-use change, conservation interventions are unlikely to succeed (Lambin et al., 2003).

We used a mixed methods approach to relate the livelihood activities of local communities to the ecology of this globally threatened species and to explore whether current conservation interventions are effective. We aimed to identify the different livelihood activities that occur in grassland habitat used by the florican, and to identify which activities pose a significant threat to survival of the species, with a particular focus on rice cultivation and wild bird hunting. We quantified the rate of uptake of dry season rice and associated technologies by local communities, documented the rationale for these changes in rice cultivation practices, and used novel methods to provide the first estimates of the prevalence of bird hunting in the Tonle Sap grasslands. We also explored people's knowledge of the presence of wild birds and their protection status. This study provides the first holistic understanding of recent change in this semi-natural, agrarian landscape, which includes both protected and unprotected grasslands, with implications for planning of future conservation of the florican.

\section{Study area}

Within Cambodia floricans are confined to small, highly fragmented populations, $80 \%$ of which reside in Kampong Thom, a province on the northern shore of the Tonle Sap lake (Packman et al., 2014). In Cambodia the florican is migratory; breeding in grasslands in the dry season (FebruaryApril), and departing at the onset of monsoonal rains (July/ August) to dipterocarp forest $30-60 \mathrm{~km}$ north of the floodplain (Packman et al., 2014). However, if conditions are suitable, floricans may remain in grasslands throughout the wet season (Packman, 2011). Floricans demonstrate natal philopatric tendencies and have complex exploded lek breeding systems, which means they require sizeable territories and large swathes of contiguous grassland habitat (Gray et al., 2007).

We surveyed 21 villages located around six study sites in Kampong Thom province. Each study site was identified as a current or former area of grassland breeding habitat subject to annual florican population monitoring (Fig. 1). At the time of research, levels of protection varied across study sites, with four sites designated as Bengal Florican Conservation Areas and two sites in unprotected areas of grassland or former grassland habitat. Bengal Florican Conservation Areas were designated under ministerial decree in 2010 and were governed by rules enforced by the Forestry Administration under the Ministry of Agriculture, Forestry and Fisheries. In May 2016 management of these Areas was transferred to the Ministry of Environment, with protection strengthened to the prime ministerial subdecree level, as the Northern Tonle Sap Conservation Landscape. For convenience, we use Bengal Florican Conservation Area to refer to individual protected sites by name, and Northern Tonle Sap Conservation Landscape to refer to all protected sites. At the time of the study, rules forbade bird hunting, land conversion and reservoir construction within Bengal Florican Conservation Areas. Levels of enforcement varied across study sites; Stoung-Chikreang Bengal Florican Conservation Areas were subject to daily patrolling, Baray and Chong-Dong Bengal Florican Conservation Areas were afforded protection in status only, and Sankor and Krous Kraom received no formal protection. Unprotected sites were open-access resources recognized as state public land under national 


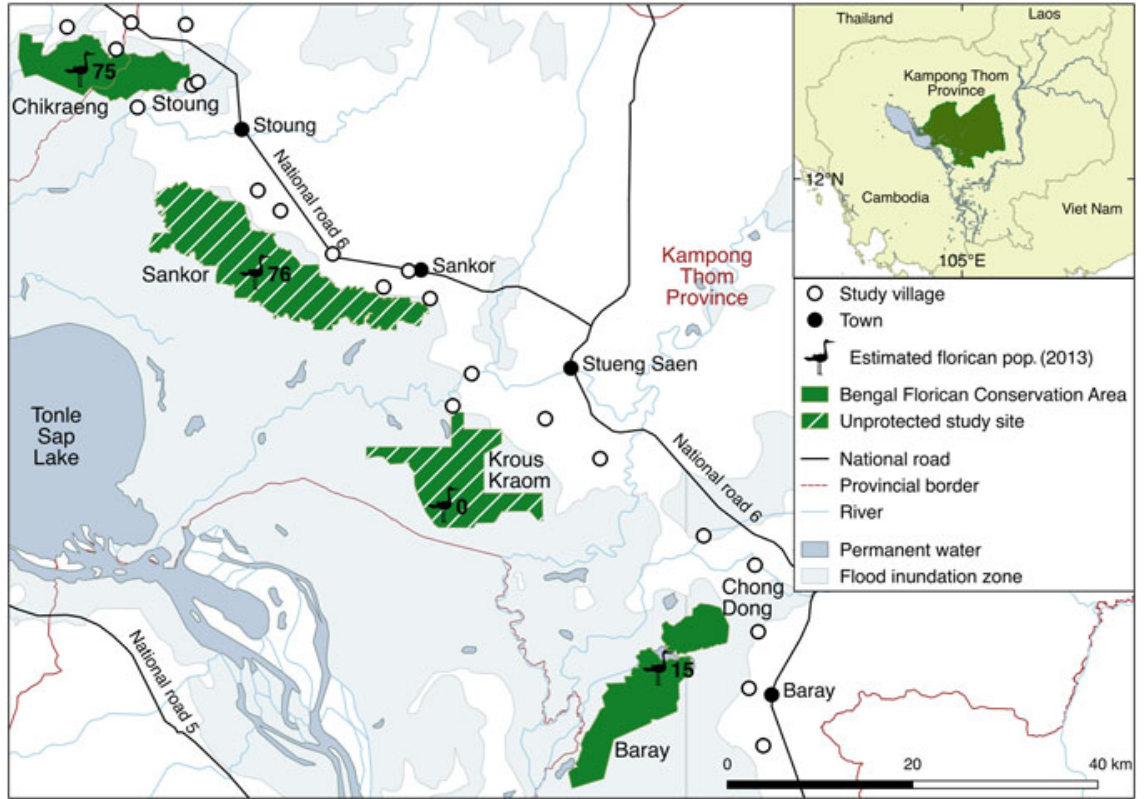

FIg. 1 The Northern Tonle Sap Conservation Landscape showing the six study sites: four formally protected Bengal Florican Conservation Areas and two unprotected grassland areas. Bengal florican Houbaropsis bengalensis population estimates, from a 2013 survey by the Wildlife Conservation Society (Mahood \& Hong, 2013), are also shown. Protected Area estimates are combined for adjacent sites; e.g. Stoung-Chikreang Bengal Florican Conservation Areas \& Chong Dong-Baray Bengal Florican Conservation Areas. law. Traditional practices such as cattle grazing and cricket collecting were encouraged in the Northern Tonle Sap Conservation Landscape under co-management frameworks overseen by Community Management Committees (Mahood \& Hong, 2013). Biodiversity monitoring, conservation outreach and enforcement activities were conducted in the Northern Tonle Sap Conservation Landscape by the government, with technical and financial assistance provided by the Wildlife Conservation Society (WCS).

\section{Methods}

Between April and May 2015, we interviewed 616 households across 21 villages, representing approximately half of the villages around the six grassland study sites. When selecting villages we aimed to capture a broad range of characteristics. Villages were selected based on their population size (45-563 households), physical location (within $10 \mathrm{~km}$ of grassland and $14 \mathrm{~km}$ of the main road) and prior participation in conservation activities. Approximately $10 \%$ of households were surveyed in each study village. To ensure broad coverage, households were selected using systematic sampling, with interviews conducted at every eighth house. If respondents declined or were absent, interviews were conducted at the next available house. Wherever possible the household head was interviewed; if unavailable, the next available adult (18+ years) was approached. All methods were piloted prior to the study.

We asked interviewees about household demographics (education level, age and gender of all household members), livelihood activities (types of activity undertaken and by whom), rice farming (when, where and how much rice was grown, if agrochemicals were used), bird sightings (species seen, frequency of sightings and location) and knowledge of protection status of selected bird species, including the florican. Household poverty levels were calculated following the Basic Necessity Survey methodology (Translinks, 2007).

We used the Unmatched Count Technique, a form of indirect questioning, to determine prevalence of illegal bird hunting and egg collection in villages. We chose this technique as it assures respondent confidentiality and is easily administered, particularly in illiterate communities (Gavin et al., 2010; Nuno et al., 2013). We randomly allocated respondents into control or treatment groups, and asked them to state the number of behaviours undertaken from a list of five. Our treatment list contained a sensitive behaviour (wild egg collecting or large bird hunting) plus four non-sensitive behaviours; the control list had four nonsensitive behaviours. Non-sensitive behaviours were the same on both control and treatment lists. Because of the small and highly fragmented nature of florican populations, we expected florican hunting to be infrequent and therefore we focused the questions on hunting of 'large game birds' to improve detectability of bird hunting behaviour. On question cards we accompanied text with a picture of an Asian openbill Anastomus oscitans, a relatively common unprotected species occurring in the Tonle Sap grasslands, based on the assumption that hunters had poor knowledge of species protection status and that if hunters were targeting larger avian species they were also more likely to hunt the florican. A warm-up question, based around fruit consumption, was first used to introduce the method to participants.

Answers to questions about hunting were triangulated through direct questioning and focus group discussions. We used picture cards featuring six bird species to ask respondents about hunting activity. We selected bird species 
TABLE 1 Status and abundance of the bird species used in bird sighting and hunting questions.

\begin{tabular}{llll}
\hline Species & Abundance in floodplain & National status & Red List status* \\
\hline Asian openbill Anastomus oscitans & Frequent & Unprotected & Least Concern \\
Bengal florican Houbaropsis bengalensis & Very rare & Protected & Critically Endangered \\
Buttonquail Coturnix sp. & Very common & Unprotected & Least Concern \\
Giant ibis Thaumatibis gigantea & Very rare & Protected & Critically Endangered \\
Sarus crane Grus antigone & Rare & Protected & Vulnerable \\
Spot-billed duck Anas poecilorhyncha & Common & Unprotected & Least Concern \\
\hline
\end{tabular}

* IUCN (2016)

based on their IUCN threat status (Least Concern to Critically Endangered), national status (protected/unprotected) and abundance in the floodplain (very common to extinct). The six species were Asian openbill, Bengal florican, small buttonquail Turnix sylvaticus, giant ibis Thaumatibis gigantea, sarus crane Grus antigone and spotbilled duck Anas poecilorhyncha (Table 1).

All questionnaires were conducted in person, were designed to avoid ambiguity, and were as concise as possible to minimize questioning time and help secure the large sample size required for the Unmatched Count Technique. Each questionnaire lasted 20-45 minutes, depending on the number of livelihood activities undertaken. All data were gathered by Cambodian research assistants, following the WCS Ethical Code of Conduct, and the study was approved through the Imperial College MSc in Conservation Science ethical review process.

We used Participatory Rural Appraisal methods to examine spatial and temporal variation in livelihood strategies (Ellis, 1999). In each village seasonal calendars and village maps were created in focus groups of 3-8 people. Participants were selected at the discretion of the village chief; typically participants were male and aged over 40. Sessions identified activities occurring in February-August, when florican numbers peak in the landscape, and included wider discussion on environmental changes and changes in land-use practices since 2005, when Gray (2008) first documented dry season rice expansion in florican breeding habitat.

Data were analysed in $R \quad$ v. 3.2.3 ( $\mathrm{R}$ Development Core Team, 2015). The Ictreg function in the List package (v. 8.o) of $R$ was used to analyse Unmatched Count Technique data (Blair et al., 2015). Generalized Linear Models (GLMs), with a binomial error structure and logit link function, were used to test for significant associations between bird hunting, bird sightings and different livelihood activities. All livelihood activities were tested individually against the response in a GLM. Significant predictors were selected for further analysis and tested for intercorrelation before inclusion in the full model. No significant correlations were found. Interactions were not included because there were no a priori reasons to expect that specific interactions would be present. Locations and distances were mapped and measured in QGIS v. 2.6.1 (QGIS, 2015).

\section{Results}

\section{Local livelihoods}

Household livelihood strategies were diverse, highly seasonal and occupied distinct spatial niches within the landscape. On average, 4.23 livelihood activities were conducted annually per household. These ranged from rice cultivation and cattle grazing to migrant work, shop keeping, fishing and collection of Non-Timber Forest Products (NTFPs) such as frogs, crickets and rats.

\section{Temporal \& spatial trends}

All on-farm livelihood activities occurred when floricans were present in the landscape (Fig. 2) but their intensity fluctuated throughout the breeding season and not all activities occurred in breeding habitat. Traditional wet season rice was sown in peak breeding season (May/June), with $76 \%$ cultivated within a $2 \mathrm{~km}$ radius of villages. On average, villages were located $3.5 \mathrm{~km}$ (range $0.4-10 \mathrm{~km}$ ) from grassland study sites, suggesting spatial overlap of wet season rice activities in florican areas was relatively low (Fig. 3).

The harvest of the first dry season rice crop from March to May and the sowing of the second dry season rice crop from May to June directly coincided with florican breeding and nesting activity (Fig. 2). The location of dry season rice fields was strongly influenced by access to irrigation sources; $37 \%$ of dry season rice was farmed $<1 \mathrm{~km}$ from the village, $24 \%$ within $1-4 \mathrm{~km}, 23 \%$ within $5-9 \mathrm{~km}$ and $16 \%>10 \mathrm{~km}$ from villages (Fig. 3). Over $70 \%$ of dry season rice fields were located south or west of villages, towards grassland habitat, with an estimated $20 \%$ of dry season rice fields situated within identified florican habitat, nearly $70 \%$ of which were located in unprotected study sites. There was high temporal and spatial overlap of dry season rice activity with florican habitat during the breeding period, particularly if a second crop was grown.

Cattle grazing occurred throughout the year, with some seasonal spatial variation. From January to July the majority of cattle were grazed within a $2 \mathrm{~km}$ radius of villages, in wet season rice fields, and thus the majority of grazing activity was unlikely to affect florican breeding areas. However, 

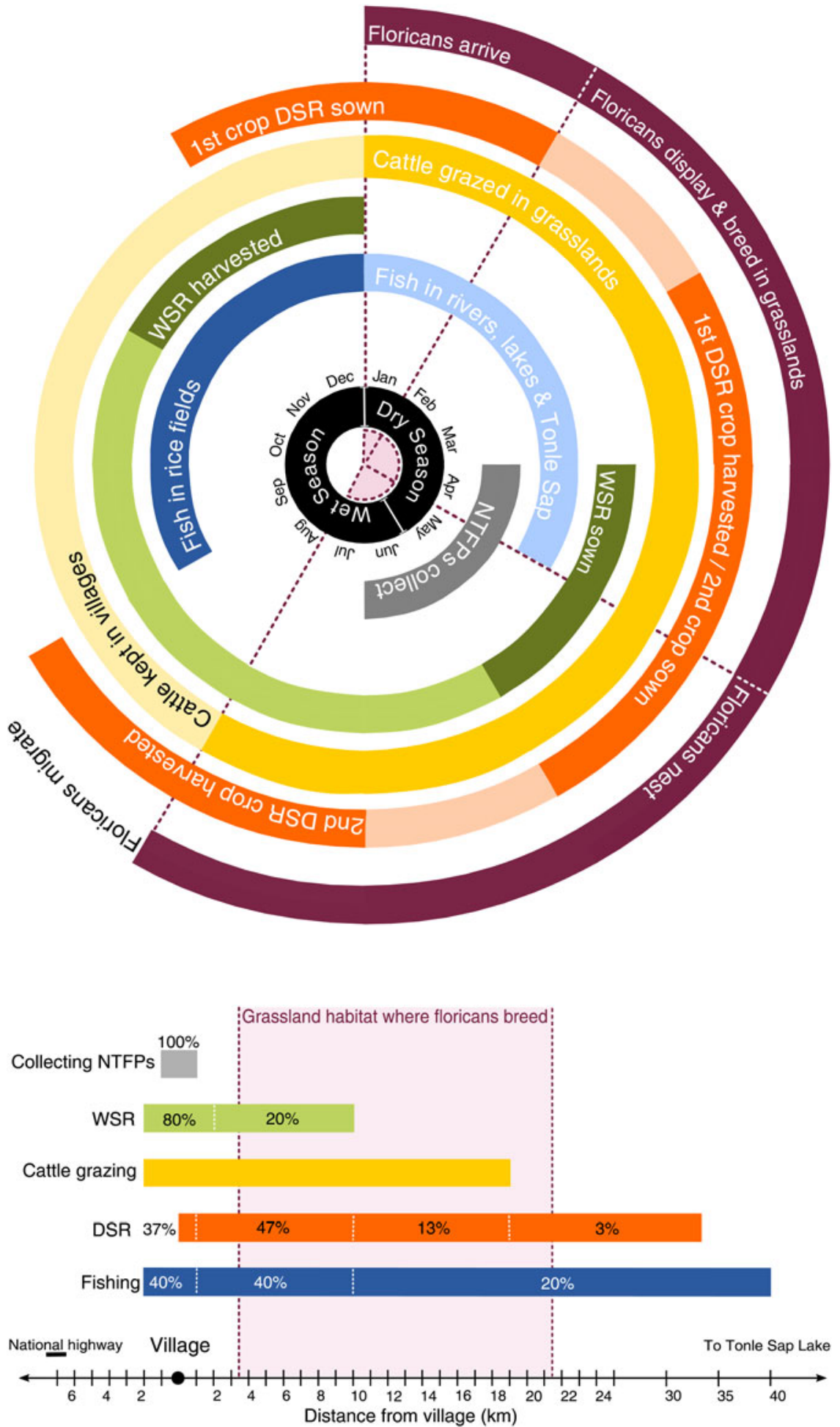

FIG. 2 Seasonal calendar displaying the livelihood activities that overlap with grassland habitat of known use by the Bengal florican in the breeding season. Within a given livelihood activity darker tones represent periods of more intense activity. DSR, dry season rice; WSR, wet season rice.

FIG. 3 Spatial distribution of livelihood activities in relation to the grassland breeding habitat used by the Bengal florican. The bottom axis represents the landscape gradient. The position of the village and each livelihood activity with respect to the highway, grassland habitat used by floricans and Tonle Sap lake is representative of the mean distance for all 21 study villages. Percentages indicate the proportion of respondents that reported carrying out this livelihood activity in this zone. DSR, dry season rice; WSR, wet season rice. occasionally cattle were grazed in grasslands, where they would either be guarded by children or men (often accompanied by dogs) or left to roam, potentially causing disturbance to floricans.

During the florican breeding season fishing activity was sporadic, except in specialist fisher households ( $n=19,3 \%$ of sample) whose fishing occurred throughout the year. In the dry season fishers typically fished in local rivers or lakes on the floodplain, or travelled to Tonle Sap lake. Fishers travelled on average $8 \mathrm{~km}$, usually by motorbike, across florican breeding habitat, to access fishing grounds.

Collection of frogs and crickets occurred at night for several days during the first rains (late April/May). Although there was temporal overlap with florican breeding activity, 
nearly all cricket collecting occurred in front of homes, except in three cases where respondents laid light traps in Stoung Bengal Florican Conservation Area. Frog collecting took place within a $1 \mathrm{~km}$ radius of villages, usually in wet season rice fields and areas unused by floricans. Nearly a quarter of households caught rats; $82 \%$ of rat catching occurred in dry season rice fields, suggesting a high degree of spatial overlap with florican habitat in the breeding season.

\section{Changes in rice cultivation}

Interviews with village chiefs revealed a rapid adoption of dry season rice within floodplain villages since 2005 (Fig. 4). 40\% of surveyed households farmed dry season rice and $46 \%$ of dry season rice farmers grew more than one crop per year. This extended the dry season rice cultivation period throughout the florican breeding season (Fig. 2).

Dry season rice cultivation was strongly associated with rat catching, with significantly more households than expected both catching rats and growing dry season rice $\left(\chi^{2}=123.6, \mathrm{df}=3, \mathrm{P}<2.2 \mathrm{e}-16\right)$. Pests and disease, including rats eating rice crops, was one of the most commonly cited factors affecting the rice harvests of rat catchers $(69 \%)$. Lacing rice with poison and distributing it across dry season rice fields was a common form of rat control. Rats were also caught alive in metal traps or bamboo snares for local consumption or sale to Vietnamese traders. Rat catching occurred at night, with farmers occasionally sleeping in fields to protect crops.

Dry season rice cultivation was also strongly associated with the use of agrochemicals; $95 \%$ of dry season rice farmers reported pesticide use, compared to $34 \%$ of wet season rice farmers. Of the 257 households that used pesticides, $78 \%$ had started since 2005. Agrochemical use was largely unregulated, with several villages reporting health and environmental concerns:

Before we did not use fertilizer but now we do as it produces a higher yield. But there is no standard for use and so people apply it at any rate they want, but this has an effect on health. Before we could drink water from the rice fields when we worked but now we cannot.

All villages reported modernization of farming techniques, including changing from transplant to broadcast sowing, mechanization of ploughing and hiring mechanical rice harvesters. Modernization was considered to have contributed to declining cattle ownership, with cattle becoming less important as draught animals.

\section{Drivers of change}

Drivers of change within communities were complex. Wet season rice was commonly grown because of 'a lack of resources to grow other types of rice' ( $25 \%$ of respondents), or because 'it is the rice grown to eat' $(16 \%)$. Other

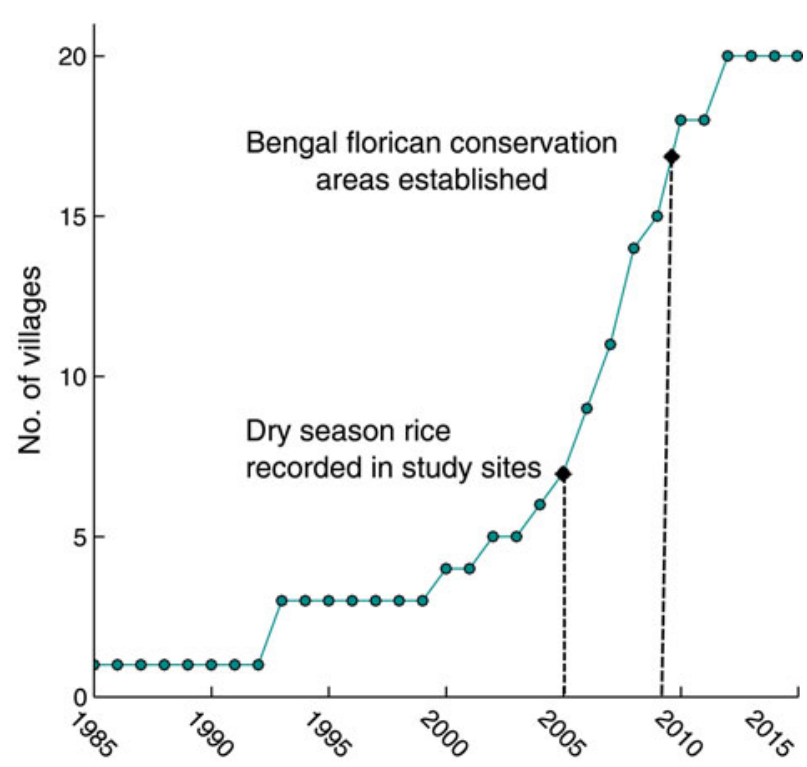

FIg. 4 Number of study villages cultivating dry season rice each year. Data are based on estimates provided by village chiefs for the year when dry season rice was first cultivated in the village.

respondents said dry season rice was preferred because it provided multiple harvests, had shorter growing periods, and higher yields. Wet season rice was regarded as a subsistence crop, whereas dry season rice was sold to generate income. Households that grew both dry and wet season rice were on average $6 \%$ wealthier than those that grew only wet season rice (Tukey comparison: difference in means $=0.0572$, confidence levels $0.092-0.022$, $\mathrm{P}<$ o.001)

Adoption of dry season rice was facilitated by the construction of reservoirs and irrigation canals by holders of Economic Land Concessions. Participants had mixed opinions as to whether quality of life had improved since 2005. Focus group participants in 16 villages stated that life had improved for the better. Reasons were threefold. Firstly, uptake of dry season rice meant households could achieve higher rice yields, improving revenue from rice sales. Secondly, mechanization of agriculture reduced labour needs, providing household members with more time to allocate to other income generating activities. Thirdly, more households were supported through remittances, as young people migrated to Phnom Penh or Thailand in search of salaried work. Nearly $50 \%$ of households were supported through remittance payments, of which $83 \%$ had started migrant work since 2010. Of the households that were supported by remittances, significantly fewer households than expected farmed dry season rice, with significantly more households than expected farming wet season rice $\left(\chi^{2}=20.246, d f=3, P=0.0001\right)$, suggesting migrant work was positively associated with wet season rice cultivation. Migrant work was the primary aspiration of parents for their children's future. 
In other villages, focus group participants believed livelihood changes had had little benefit for quality of life. Several participants spoke of increased debt, particularly amongst dry season rice farmers as they borrowed finance to purchase seed and agrochemicals. If harvests failed or rice prices dropped, farmers were often forced to sell assets, including land, to pay debts, which resulted in greater inequality.

\section{Prevalence of bird hunting}

When questioned directly $8.6 \%$ of households reported hunting birds in the previous 12 months. Hunting was nonselective. Small, abundant, game-birds, such as buttonquail spp. (reported by $87 \%$ of bird hunters) and spot-billed ducks (26\%), were caught most frequently, although captures of larger species such as storks and sarus cranes were also recorded. Eighty-three percent of hunting households caught birds to eat, $15 \%$ caught birds to eat and sell, and one respondent reported hunting only for profit. Birds were hunted at night, by hand, or with slingshots, bamboo snares or fishing nets. Several fishers reported accidental capture of ducks and herons or egrets whilst fishing or when nets were strung around dry season rice fields ostensibly to protect against rats. Two percent of respondents observed bird hunting or bird meat sales in their village. In two villages, focus group participants said local people targeted herons or egrets to sell to traders. The trial Unmatched Count Technique question identified a significant difference between control and treatment groups, suggesting Unmatched Count Technique was working as expected (because the mock sensitive fruit item was one likely to have been eaten by a substantial number of people). However, no significant difference was identified between control and treatment groups for egg collecting ( $\mathrm{df}=615, t=-0.084, \mathrm{P}=0.933)$ or large bird hunting $(\mathrm{df}=615, t=-0.451, \mathrm{P}=0.652)$, suggesting the prevalence of these activities did not significantly differ from zero.

No respondents self-reported hunting the florican, although some incidences of hunting were recorded secondhand. One focus group participant said a villager caught a florican 2-3 years previously, another said someone tried to sell a live florican for KHR 100,000 (USD 25) in the village 2 years previously. Fishers reported accidental capture of floricans in abandoned fishing nets.

\section{Hunter profiles}

Respondents who reported bird hunting were typically male, and likely to belong to households that collected frogs or caught rats (Table 2). This is credible considering these livelihood activities were predominantly undertaken by men and occurred at night, when enforcement patrols were less active and roosting birds more vulnerable.
TABLE 2 Parameter estimates of the General Linear Model testing for the effect of respondent gender and household livelihood activities on whether a household $(n=616)$ hunted birds.

\begin{tabular}{llll}
\hline & Estimate & $\mathrm{SE}$ & $\mathrm{P}$ \\
\hline Intercept & -3.6428 & 0.3908 & $<2 \mathrm{e}-16^{* * *}$ \\
Livelihood activity & & & \\
Respondent gender: male & 0.8543 & 0.3294 & $0.00950^{\star *}$ \\
Rat catcher & 0.8023 & 0.3060 & $0.00875^{\star *}$ \\
Fisher & 0.1735 & 0.3777 & 0.64594 \\
Frog collector & 0.7429 & 0.3137 & $0.01789^{*}$ \\
\hline
\end{tabular}

${ }^{*},<0.01 ;{ }^{* *},<0.001 ;{ }^{* *},<0.0001$

Whether households hunted birds was not associated with household wealth (Wilcoxon test, $W=15,350, \mathrm{P}=0.7288$ ).

Reported prevalence of bird hunting was highest in the two unprotected study sites, Sankor (14\% of respondents) and Krous Kraom (10\%). Stoung-Chikreang Bengal Florican Conservation Areas, sites with the greatest enforcement activity, had the lowest prevalence of bird hunting $(<4 \%)$. There was a significant difference between hunting levels in unprotected sites and Bengal Florican Conservation Areas $\left(\chi^{2}=8.216, \mathrm{df}=1, \mathrm{P}=0.004\right)$ but results may have been influenced by social desirability bias.

\section{Florican sightings and local conservation knowledge}

$29 \%$ of respondents had seen floricans in the previous year, c. $2 \%$ saw floricans daily and $5 \%$ saw floricans multiple times monthly; $61 \%$ of sightings were in grassland habitat and $27 \%$ in dry season rice fields. Male respondents belonging to households that farmed dry season rice, or collected rats, frogs or crickets, were significantly more likely to sight floricans (Table 3), bearing out the suggestion that these activities have most spatio-temporal overlap with florican presence (Figs $2 \& 3$ ). Sighting levels varied between sites, and were highest in Stoung-Chikraeng Bengal Florican Conservation Areas (0.59 sightings per household in the previous year), and lowest in Chong Dong-Baray Bengal Florican Conservation Areas (0.09 sightings per household). The probability of florican sightings in StoungChikraeng Bengal Florican Conservation Areas and Sankor was significantly higher than at other sites, which was expected as these sites have larger florican populations (Table 2).

Over half of respondents correctly said floricans were protected, with greater knowledge amongst males than females $\left(\chi^{2}=45.031, \mathrm{df}=1, \mathrm{P}=1.939 \mathrm{e}-11\right)$. Knowledge varied between sites and was highest in Stoung-Chikraeng Bengal Florican Conservation Areas (73\%) and lowest in unprotected areas such as Sankor $(19 \%) ;<1 \%$ of respondents assigned all six bird species to the correct protection categories. Our findings should be considered with caution, 
TABLE 3 Parameter estimates of General Linear Model testing for the effect of respondent gender, livelihood activities and site on whether a respondent $(\mathrm{n}=616)$ saw a Bengal florican Houbaropsis bengalensis.

\begin{tabular}{llll}
\hline & Estimate & SE & $\mathrm{P}$ \\
\hline Gender: male & 1.104 & 0.225 & $9.52 \mathrm{e}-07^{* * *}$ \\
$\begin{array}{l}\text { Livelihood activity } \\
\text { Dry season rice farmer }\end{array}$ & 1.049 & 0.251 & $2.99 \mathrm{e}-05^{* * *}$ \\
Wet season rice farmer & 0.220 & 0.305 & 0.470 \\
Rat catcher & 0.547 & 0.269 & $0.042^{*}$ \\
Cricket collector & 0.720 & 0.266 & $0.006^{* *}$ \\
Fisher & 0.140 & 0.252 & 0.579 \\
Frog collector & 0.493 & 0.225 & $0.028^{*}$ \\
Site & & & \\
Baray Bengal Florican & & & \\
Conservation Area (Intercept) & & & \\
Chikreang Bengal Florican & 2.913 & 0.526 & $3.06 \mathrm{e}-08^{* * *}$ \\
Conservation Area & & & \\
Chong Doung Bengal Florican & 0.161 & 0.608 & 0.791 \\
Conservation Area & & & \\
Krous Kroam & 0.088 & 0.444 & 0.842 \\
Sankor & 1.120 & 0.501 & $0.025^{*}$ \\
Stoung Bengal Florican & 2.305 & 0.504 & $4.90 \mathrm{e}-06^{* * *}$ \\
Conservation Area & & & \\
\hline
\end{tabular}

${ }^{*},<0.01 ;^{* *},<0.001{ }^{* * *},<0.0001$

however, as nearly $30 \%$ of respondents incorrectly said all six bird species featured on question cards were protected, suggesting responses may have been influenced by social desirability bias rather than actual knowledge. There is also ambiguity in the question as all birds are protected in the Bengal Florican Conservation Areas. Despite this, people living near Bengal Florican Conservation Areas were less likely to incorrectly identify all species as protected $\left(\chi^{2}=5.616, \mathrm{df}=1, \mathrm{P}=0.017\right)$

\section{Discussion}

\section{Agricultural expansion and intensification}

Prior to this research, habitat loss fuelled by intensive dry season rice cultivation was known to be the greatest threat to the survival of world's largest remaining Bengal florican population but conservation managers lacked adequate understanding of the socioeconomic factors driving land-use change. It was assumed dry season rice cultivation was an industrial activity driven largely by external businessmen (Gray, 2008). We found dry season rice is now a common, attractive and financially profitable livelihood activity undertaken by a significant proportion of local people. This suggests that current conservation interventions that prevent the expansion of rice cultivation in the Northern Tonle Sap Conservation Landscape may be inflicting opportunity costs on communities bordering the Landscape if they do not have access to suitable land elsewhere. Contradictorily, dry season rice uptake was also implicated in increased inequality and debt burdens (Lambin et al., 2003).

It was previously believed that all farmers cultivated only one crop of dry season rice, between December and April (Gray, 2008); this was probably correct until the mid 20oos. However, our findings suggest nearly half of dry season rice farmers now cultivate two crops per year, extending human presence in the grassland landscape into the florican breeding season in July/August. This finding is potentially devastating for the florican, as our results show strong spatial overlap between dry season rice fields and the florican's grassland breeding habitat. Although the florican can persist in dry season rice areas by utilizing dams for nesting and stubble for displaying, this is only possible after water has been used up and the first crop has been harvested (Mahood \& Hong, 2013; Packman et al., 2014). We confirmed that dry season rice expansion by local communities is primarily facilitated by external development of irrigation sources, and thus governmental and donor-driven initiatives to enhance agricultural infrastructure on the floodplain are likely to exacerbate future grassland loss and population declines (MAFF, 2015). Models of lesser florican Sypheotides indica populations in Indian agro-grassland landscapes document similar trends as a result of irrigation development (Dutta \& Jhala, 2014).

Increased agrochemical use plays an important role in agricultural intensification (Tilman et al., 2001); this also holds true for dry season rice cultivation on the Tonle Sap grasslands. This is of particular concern as studies of other bustard species report significant reductions in population density as a result of pesticide-associated food declines (Martínez \& Tapia, 2002). Pesticides used in Cambodia include those banned elsewhere, such as DDT, a toxic substance known to bio-accumulate and cause egg thinning in birds (Fry, 1995). Although little is known about the dietary preferences of the florican, insects may form a primary dietary component (Mahood \& Hong, 2013). Bengal floricans have been found to actively forage in dry season rice stubble (Gray, 2008) and thus increased pesticide use could have significant impacts on the survival of the florican and other grassland species. At a landscape level agrochemical use degrades ecosystems and undermines the health of livelihoods and ecosystems across the Tonle Sap floodplain (Bonheur \& Lane, 2002). Anecdotal evidence from unprotected sites in the Northern Tonle Sap Conservation Landscape suggests that the cultivation of multiple dry season rice crops per year rapidly exhausts soil fertility; even with extensive chemical input, dry season rice fields are often abandoned after 5-10 years. Once abandoned, fields are colonized by a dense homogeneous grass sward that is of no commercial value and is unsuitable for the florican. 


\section{Modernization and mechanization}

We identified a surge in the use of motorized hand tractors over the last 10 years, with declines in cattle ownership as farmers sold assets to buy machinery; a trend documented elsewhere in Cambodia (Clements \& Milner-Gulland, 2015). Mechanization rapidly increases the ease with which land can be transformed, and reduces the need for animals for agricultural use. Historically, livestock grazing played an important role in maintaining grassland structure and the suitability of florican habitat (Gray et al., 2009; Roberts, 2011). Previous declines in cattle grazing have already significantly encouraged scrub encroachment and reduced habitat quality across the floodplain (Packman et al., 2013); the trends we observed are likely to exacerbate this process.

\section{Direct impacts on grassland bird populations}

Previous research identified hunting as a threat to the florican but failed to quantify the level of threat (Packman, 2011). Using the Unmatched Count Technique we did not identify large bird hunting or egg collection as activities undertaken by a significant proportion of the population, but we found evidence of grassland bird hunting; when asked directly, $8.6 \%$ of respondents said they hunted wild birds. Realistically, levels are probably considerably higher as participants are likely to have underreported sensitive behaviour (Gavin et al., 2010). Discussions in villages revealed a local market for wild bird meat, and 43 market surveys conducted by WCS during January 2014-May 2015 identified wild bird meat for sale on three occasions (SM, pers. obs.). Together, these results confirm previous findings that wild bird meat plays a role in the diets of Tonle Sap floodplain communities (Bonheur \& Lane, 2002). Our evidence suggests bird hunting is occurring in florican breeding areas. Given the scarcity of the species, incidences of florican capture are likely to be opportunistic, untargeted and rare; however, offtake of even a few individuals could significantly affect population viability. Should sufficient market demand develop, low income levels, combined with reportedly high market prices (USD 25 per bird according to focus group participants), could make targeting the florican financially attractive. Therefore, our results suggest that hunting could pose a significant threat to the future of the florican in the Tonle Sap floodplain (as also suggested by Packman, 2011).

\section{Conservation needs}

Although assessing the impact of conservation interventions was beyond the scope of this study, our results provide useful information on the effectiveness of actions to date. Levels of bird hunting and conversion of grassland to dry season rice were higher in non-protected grasslands (Sankor, Krous Kraom) and poorly protected Bengal Florican Conservation Areas (Baray-Chong Dong) than in well-protected Bengal Florican Conservation Areas (Stoung-Chikraeng). Therefore, extending conservation efforts to unprotected grassland sites that support high florican populations, such as Sankor, should be a high priority. Despite heavy fragmentation, this site still has a large area of grassland habitat and is one of the largest remaining Bengal florican breeding populations. Knowledge of florican conservation was lowest at this site and levels of bird hunting were highest, suggesting communities in Sankor should be a primary target for conservation engagement. Profiling revealed dry season rice farmers and those who collected nontimber forest products were most likely to see floricans, and therefore these grassland user groups should be key targets for future conservation interventions.

\section{The future of the Bengal florican}

Conservation of the Bengal florican currently focuses on protecting remaining grassland habitat through the Northern Tonle Sap Conservation Landscape, yet both our study and previous findings reveal that this Landscape is subject to considerable encroachment from dry season rice (Mahood \& Hong, 2013). Desire for expansion of this crop is high amongst local communities because of the perceived financial benefits compared to those provided by traditional livelihood activities. In 2015 the Cambodian government released a new 4-year agricultural strategy advocating intensive development of the agricultural sector, including dry season rice across the Tonle Sap floodplain (MAFF, 2015). It is therefore highly likely that pressure to convert remaining grasslands will escalate. Although political will to protect grasslands has substantially increased since the transferral of the Northern Tonle Sap Conservation Landscape to the Ministry of Environment in early 2016, this needs to be maintained. Although some conservation measures appear to be working (when adequately enforced), substantial investment in community engagement, education and outreach is urgently needed to secure successful outcomes. However, even if perfect protection is established, the current size of the individual Bengal Florican Conservation Areas is thought to be too small to support viable breeding populations because of the species' large home range (Packman et al., 2014). Already a significant proportion of floricans persist outside the Northern Tonle Sap Conservation Landscape in converted or increasingly sub-optimal grassland habitat (Packman, 2011; Packman et al., 2014); our findings highlight the urgent need to find land-sharing interventions that work with dry season rice farmers beyond the borders of this Landscape. 
To date, wildlife-friendly farming has been largely confined to western agri-environment schemes, but there have been increasing calls for greater application in developing countries (Wright et al., 2012). Our research revealed local concerns about pesticide use and agricultural sustainability. Furthermore, current rules associated with the Northern Tonle Sap Conservation Landscape limit opportunities for development within the protected areas. To be effective, conservation interventions must promote, not prevent, social development (Norris, 2008). Conservation measures that curtail economic growth or constrain livelihood opportunities must be adequately compensated to prevent stakeholder discontent, and improve long-term viability (Adams et al., 2004). Supporting one-crop dry season rice farmers to improve agricultural practices in the areas adjacent to the Northern Tonle Sap Conservation Landscape could present an opportunity to pilot wildlife-friendly farming in the region and to improve florican habitat suitability at a landscape scale.

One potential opportunity lies in the Sustainable Rice Platform, a global initiative to improve all aspects of sustainability in commercial rice production, with membership across NGOs, governments and the private sector. The Platform has established 46 Sustainability Standards, which include measures related to encroachment on protected areas, use of chemicals and methods of pest management. Farmers who adopt the Platform must make improvements in all relevant aspects of sustainability as measured by the standards, including yield, farm efficiency, biodiversity, chemical and labour inputs, poverty, and social measures such as child labour and status of women. Within unprotected areas used by the florican, farmers who grow rice according to the Sustainability Standards could receive improved access to lucrative export markets if assisted to improve the suitability of their rice fields for the florican. Through the Platform the private sector has the potential to reconcile conservation and development in impoverished rural communities, which in turn could prevent the extinction of the Bengal florican. The research reported here enabled WCS to secure funding to pilot the Sustainable Rice Platform in seven villages around Stoung-Chikraeng Bengal Florican Conservation Areas. The pilot phase is ongoing, with plans to scale activities up to engage 400 farmers by 2018 .

\section{Acknowledgements}

Special thanks go to all our interviewees for their participation. We thank the Royal Government of Cambodia for permission to carry out this research, which was funded by Chester Zoo Act for Wildlife Fund, Tropical Agriculture Association Award Fund, Imperial College London, WCS Cambodia and the UK National Environment Research Council (Grant ref. NE/Noo1370/1).

\section{Author contributions}

The research was led by $\mathrm{HI}$, with guidance from $\mathrm{SM}, \mathrm{CH}$ and EJMG. SM and $\mathrm{CH}$ provided site specific knowledge and technical support. EJMG provided technical advice, particularly on methods and analysis. Data were collected by CL, PP and DS under the supervision of HI. HI, SM and EJMG devised the paper structure, and HI authored, with input and revisions from SM and EJMG.

\section{References}

Adams, W., Aveling, R. \& Brockington, D. (2004) Biodiversity conservation and the eradication of poverty. Science, 306, 1146-1149. Birdife International (2003) Saving Asia's Threatened Birds: A Guide for Government and Civil Society. BirdLife International, Cambridge, UK.

Birdife International (2015) Houbaropsis bengalensis. The IUCN Red List of Threatened Species 2015. Http://dx.doi.org/10.2305/IUCN. UK.2015-4.RLTS.T22692015A82252874.en [accessed 19 April 2016].

Blair, G., Imai, K., Park, B. \& Coppock, A. (2015) Statistical Methods for the Item Count Technique and List Experiment. Version 8.o Https://cran.r-project.org/web/packages/list/index.html [accessed 12 October 2015].

Bond, W.J. \& PARR, C.L. (2010) Beyond the forest edge: ecology, diversity and conservation of the grassy biomes. Biological Conservation, 143, 2395-2404.

Bonheur, N. \& LANe, B.D. (2002) Natural resources management for human security in Cambodia's Tonle Sap Biosphere Reserve. Environmental Science \& Policy, 5, 33-41.

Clements, T. \& Milner-Gulland, E.J. (2015) Impact of payments for environmental services and protected areas on local livelihoods and forest conservation in northern Cambodia. Conservation Biology, 29, 78-87.

Curtin, C. \& Western, D. (2008) Grasslands, people, and conservation: over-the-horizon learning exchanges between African and American pastoralists. Conservation Biology, 22, 870-877.

Dutta, S. \& Jhala, Y. (2014) Planning agriculture based on land use responses of threatened semiarid grassland species in India.

Biological Conservation, 175, 129-139.

Ellis, F. (1999) Rural livelihood diversity in developing countries: evidence and policy implications. Natural Resource Perspectives, 40, 1-10.

FRY, D.M. (1995) Reproductive effects in birds exposed to pesticides and industrial-chemicals. Environmental Health Perspectives, 103, $165-171$.

Gavin, M.C., Solomon, J.N. \& Blank, S.G. (2010) Measuring and monitoring illegal use of natural resources. Conservation Biology, 24, 89-100.

Gray, T.N.E. (2008) The conservation and ecology of the Bengal florican Houbaropsis bengalensis in Cambodia: grasslands, people and management. PhD thesis. University of East Anglia, Norwich, UK.

Gray, T.N.E., Chamnan, H., Borey, R., Collar, N.J. \& Dolman, P.M. (2007) Habitat preferences of a globally threatened bustard provide support for community-based conservation in Cambodia. Biological Conservation, 138, 341-350.

Gray, T.N.E., Chamnan, H., Collar, N.J. \& Dolman, P.M. (2009) Sex-specific habitat use by a lekking bustard: conservation implications for the Critically Endangered Bengal florican in an intensifying agroecosystem. The Auk, 126, 112-122. 
Green, R.E., Cornell, S.J., Scharlemann, J.P.W. \& Balmford, A. (2005) Farming and the fate of wild nature. Science, 307, 550-555.

Hoekstra, J.M., Boucher, T.M., Ricketts, T.H. \& Roberts, C. (2005) Confronting a biome crisis: global disparities of habitat loss and protection. Ecology Letters, 8, 23-29.

IUCN (2016) IUCN Red List of Threatened Species. Version 2016-3. [accessed 14 February 2017].

Lambin, E.F., Geist, H.J. \& Lepers, E. (2003) Dynamics of land-use and land-cover change in tropical regions. Annual Review of Environment and Resources, 28, 205-241.

MAFF (2015) Agricultural Sector Strategic Development Plan 2014-2018. Ministry of Agriculture, Forestry \& Fisheries, Phnom Penh, Cambodia.

Mahood, S. \& Hong, C. (2013) Finding a Place for the Bengal Florican in an Agricultural Landscape. Wildlife Conservation Society, Phnom Penh, Cambodia.

Martínez, C. \& Tapia, G. (2002) Density of the little bustard Tetrax tetrax in relation to agricultural intensification in central Spain. Ardeola, 49, 301-304.

Milner-Gulland, E.J. (2012) Interactions between human behaviour and ecological systems. Philosophical Transactions of the Royal Society $B, 367,270-278$.

Norris, K., (2008) Agriculture and biodiversity conservation: opportunity knocks. Conservation Letters, 1, 2-11.

Nuno, A., Bunnefeld, N., Naiman, L.C. \& Milner-Gulland, E.J. (2013) A novel approach to assessing the prevalence and drivers of illegal bushmeat hunting in the Serengeti. Conservation Biology, 27, 1355-1365.

PACKMAN, C.E. (2011) Seasonal landscape use and conservation of a Critically Endangered bustard: Bengal florican in Cambodia. $\mathrm{PhD}$ thesis. University of East Anglia, Norwich, UK.

Packman, C.E., Gray, T.N.E., Collar, N.J., Evans, T.D., Van Zalinge, R.N., ViraK, S. et al. (2013) Rapid loss of Cambodia's grasslands. Conservation Biology, 27, 245-247.

Packman, C.E., Showler, D.A., Collar, N.J., Virak, S., Mahood, S.P., Handschun, M. et al. (2014) Rapid decline of the largest remaining population of Bengal florican Houbaropsis bengalensis and recommendations for its conservation. Bird Conservation International, 24, 429-437.
Parr, C.L., Lehmann, C.E.R., Bond, W.J., Hoffmann, W.A. \& Andersen, A.N. (2014) Tropical grassy biomes: misunderstood, neglected, and under threat. Trends in Ecology \& Evolution, 29, 205-213.

QGIS (2015) QGIS: A Free and Open Source Geographic Information System. Http://www.qgis.org/en/site/ [accessed 18 June 2015].

R Development Core Team (2015) R: A Language and Environment for Statistical Computing. R Foundation for Statistical Computing, Vienna, Austria. Http://www.R-project.org [accessed 10 December 2015].

Roberts, A. (2011) Phytosociology, history and diversity in farmermanaged landscapes on the Tonle Sap floodplain, Cambodia. $\mathrm{PhD}$ thesis. The City University of New York, New York, USA.

Tilman, D., Fargione, J., Wolff, B., D’Antonio, C., Dobson, A., Howarth, R. et al. (2001) Forecasting agriculturally driven global environmental change. Science, 292, 281-284.

Translinks (2007) Livelihood Surveys. A Tool for Conservation Design, Action and Monitoring. Wildlife Conservation Society, New York, USA, and USAID, Washington, DC, USA.

White, R., Rohweder, M. \& Murray, S. (2000) Grassland ecosystems. In Pilot Analysis of Global Ecosystems: Grassland Ecosystems. World Resources Institute, Washington, DC, USA.

Wright, H.L., Lake, I.R. \& Dolman, P.M. (2012) Agriculture-a key element for conservation in the developing world. Conservation Letters, 5, 11-19.

\section{Biographical sketches}

Harriet Iв вет t investigates illegal resource use, law enforcement and human decision making behaviour in protected areas across Cambodia. Chansetha Lay and Ponlork Phlai continue to work with WCS Cambodia as research assistants, and DET SONG is a research assistant at ECOLAND Research Centre. Chamnan Hong is the Director of the Bengal Florican Conservation Areas. Sim on MAH O od is the Senior Technical Advisor for WCS Cambodia. E. J. Milner-Gulland is the leader of the Interdisciplinary Centre for Conservation Science (http:// www.iccs.org.uk). 